\title{
KONEKTIVITAS ANGKUTAN KERETA API DENGAN ANGKUTAN JALAN ( STUDI KASUS : STASIUN TAMBUN, BEKASI )
}

\author{
Subarto, ATD, MM \\ Dosen STTD \\ Jl. Raya Setu No. 89, Bekasi \\ Telp./Fax : (021) 8254640 \\ Dr. Gloria Novita C., MT \\ Dosen STTD \\ Jl. Raya Setu No. 89, Bekasi \\ Telp./Fax : (021) 8254640
}

\author{
Ir.Djamal Subastian, M.Sc \\ Dosen STTD \\ Jl. Raya Setu No. 89, Bekasi \\ Telp./Fax : (021) 8254640
}

\author{
Sahar Andika, SH, MH \\ Dosen STTD \\ Jl. Raya Setu No. 89, Bekasi \\ Telp./Fax : (021) 8254640
}

\begin{abstract}
Bekasi Regency area that is vast and most of the population working in the Jabotabek area causes the need for public transportation that has a long enough travel characteristics, see traffic condition and the condition of road network is not good. So that the service of rail transport (KA) becomes very important. Since the opening of train service from CikarangJakarta which also serve Tambun station, the number of passengers who got up/down at Tambun station continues to increase. The characteristics of train passengers at Tambun station, about $60 \%$ using motorcycles and motorcycle taxis and only $23 \%$ are using public transportation.

Passenger train at the station Tambun $70 \%$ dominant stated that public transport service is good, but only $30 \%$ from non-public transport users who are willing to move mode to public transport if the service is provided. Currently there are 9 public transport routes with 156 units of vehicles that can serve passengers to/from the station Tambun, Bekasi; But with less good performance and tend to be bad. The improvement of public transport services can be mainly on headway, scheduling (eliminating ngetem) and extending operating hours, and all of them can still be accommodated by the number of vehicles currently operating (no need for the addition of a fleet).
\end{abstract}

\section{Keywords : Transport, Station, Passenger}

\footnotetext{
ABSTRAKSI

Wilayah Kabupaten Bekasi yang luas dan sebagian besar penduduknya yang bekerja di wilayah Jabotabek ini menyebabkan adanya kebutuhan terhadap angkutan umum yang memiliki karakteristik perjalanan yang cukup panjang, melihat kondisi lalu lintas dan kondisi jaringan jalan yang kurang baik. Sehingga adanya pelayanan angkutan kereta api (KA) menjadi sangat penting. Sejak dibukanya layanan kereta api dari Cikarang-Jakarta yang juga
} 
melayani Stasiun Tambun, jumlah penumpang yang naik/ turun di Stasiun Tambun terus meningkat.

Karakteristik penumpang kereta api di Stasiun Tambun, sekitar $60 \%$ menggunakan sepeda motor dan ojek dan hanya $23 \%$ yang menggunakan angkutan umum. Penumpang kereta api di Stasiun Tambun $70 \%$ dominan menyatakan bahwa layanan angkutan umum baik, namun hanya 30\% dari non-pengguna angkutan umum yang bersedia pindah moda ke angkutan umum jika disediakan layanan angkutan. Saat ini terdapat 9 trayek angkutan umum dengan jumlah kendaraan 156 unit yang dapat melayani penumpang menuju/ meninggalkan Stasiun Tambun, Bekasi; namun dengan kinerja yang kurang baik dan cenderung buruk. Peningkatan layanan angkutan umum dapat diutamakan khususnya pada headway, penjadwalan (menghilangkan ngetem) dan memperpanjang jam operasional, dan semuanya masih dapat diakomodir oleh jumlah kendaraan yang beroperasi saat ini (tidak perlu penambahan armada).

\section{Kata Kunci :Transportasi, Stasiun, Penumpang}

\section{PENDAHULUAN}

Angkutan kereta Api sebagai bagian penting dari sistim angkutan umum di Indonesia dan merupakan salah satu elemen dari sistem transportasi perkotaan yang memegang peran yang sangat penting bagi suatu daerah atau wilayah. Salah satu indikator dari wilayah yang dapat ditandai, antara lain dengan melihat kondisi sistem transportasi khususnya angkutan umumnya.

Karakter wilayah Kabupaten Bekasi yang luas dan sebaran penduduk yang relatif merata dan dimana sebagaian besar penduduknya bekerja diluar kota atau di wilayah Jabotabek menyebabkan adanya kebutuhan terhadap angkutan umum yang memiliki karakteristik perjalanan yang cukup panjang, sehingga diperlukan jenis angkutan yang dapat melayani perjalanan jarak jauh, melihat kondisi lalu lintas dan kondisi jaringan jalan yang kurang baik menyebabkan pelayanan angkutan umum dengan basis jalan menjadi kurang optimal, sehingga adanya pelayanan angkutan kereta api (KA) menjadi sangat penting.

Di samping itu, rute angkutan umum yang baik harus dapat dapat menjangkau seluruh wilayah dan memenuhi kepentingan beberapa pihak terkait seperti penumpang (user), pengelola (operator) dan pemerintah (regulator), namun agar lebih optimal angkutan KA 
harus didukung oleh peyanan angkutan angkutan umum berbasis jalan sehingga tercipta konektivitas antara berbagai jenis pelayanan.

Dinas Perhubungan Kabupaten Bekasi sebagai pembina transportasi di Kabupaten Bekasi tentunya sangat berkepentingan dalam membina angkutan umum di wilayahnya. Salah satu wujud pembinaan (perencanaan, pengaturan dan pengendalian pelayanan angkutan umum) yaitu melakukan kegiatan perencanaan pelayanan angkutan umum dalam trayek tetap dan teratur, khususnya angkutan perdesaan di Kabupaten Bekasi. Khususnya evaluasi konektivitas antara angkutan umum kereta api dengan angkutan umum lainnya.

\section{TUJUAN PENELITIAN}

Tujuan dari penelitian penelitian tentang Konektivitas Angkutan Kereta Api Dengan Angkutan Jalan ( Studi Kasus : Stasiun Tambun, Bekasi ) adalah :

a. Untuk meningkatkan pelayanan Angkutan umum di Instansi dan wilayah terkait.

b. Peranan angkutan kereta api dalam wilayah Kabupaten Bekasi.

\section{SASARAN PENELITIAN}

Sasaran utama studi ini lebih diarahkan sebagai bahan evaluasi dalam penetapan kebijakan perencanaan, angkutan jalan (trayek) yang berbasis pada konektivitas pelayanan kereta api pada Stasiun Tambun.

\section{RUANG LINGKUP PENELITIAN}

a. Ruang Lingkup Wilayah

Ruang lingkup yang menjadi wilayah studi dari kegiatan ini adalah wilayah Kabupaten Bekasi.

b. Ruang Lingkup Studi

Adapun rincian ruang lingkup studi ini adalah pada operasional angkutan umum pada wilayah Stasiun Tambun.

\section{KELUARAN HASIL PENELITIAN}

Keluaran dari penelitian ini adalah berupa rekomendasi dari trayek-trayek angkutan umum yang melalui stasiun Tambun menuju daerah-daerah asal-tujuan penumpang yang menggunakan angkutan kereta api (Commuter Line-CL). 


\section{METODOLOGI PENELITIAN}

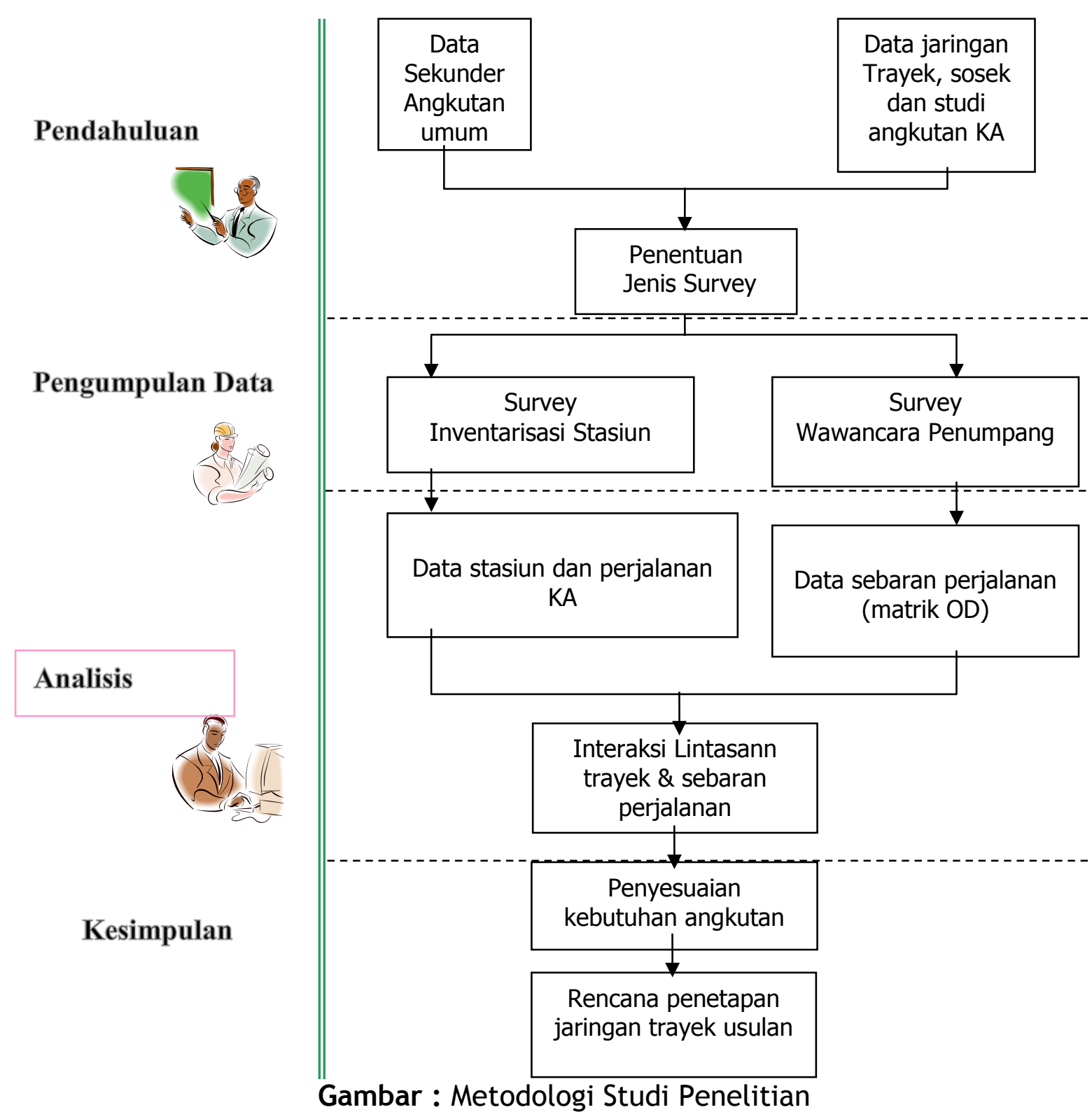

\section{ANALISIS DAN PEMBAHASAN}

\section{Jaringan Pelayanan Angkutan Umum}

Yang dimaksud dengan jaringan pelayanan angkutan umum adalah jaringan trayek yang dilengkapi dengan terminal dan tempat perhentian, untuk wilayah sekitar Stasiun Tambun, angkutan umum dalam trayek yang melayani adalah: trayek Angkutan Pedesaan dan 
trayek Angkutan Antar Kota Dalam Propinsi-AKDP. Angkutan Perdesaan tersebut melayani pergerakan masyarakat antar kecamatan di Kabupaten Bekasi, sedangkan AKDP melayani pergerakan masyarakat antar kota/ kabupaten di Provinsi Jawa Barat.

Tabel. : Daftar nama trayek dan jumlah armada, Kabupaten Bekasi

\begin{tabular}{|c|c|c|c|c|}
\hline No & $\begin{array}{l}\text { NOMOR } \\
\text { TRAYEK } \\
\end{array}$ & URAIAN TRAYEK & $\begin{array}{l}\text { JUMLAH } \\
\text { ARMADA } \\
\end{array}$ & KET. \\
\hline 1 & $\mathrm{~K}-14$ & Kp Utan - Setu - Serang pp & 88 & aktif \\
\hline 2 & $\mathrm{~K}-14 \mathrm{~A}$ & $\begin{array}{l}\text { Setu - Cibening - Psr Serang - } \\
\text { Lippo City pp }\end{array}$ & 4 & aktif \\
\hline 3 & $\mathrm{~K}-16$ & $\begin{array}{l}\text { Tambun - Tambelang - Balong } \\
\text { asem pp }\end{array}$ & 10 & aktif \\
\hline 4 & $\begin{array}{l}\mathrm{K}-16 \\
\mathrm{BV}\end{array}$ & Tambun - Perum Villa Bekasi Indah. & 14 & aktif \\
\hline 5 & $\begin{array}{l}\mathrm{K}-16 \\
\mathrm{BG}\end{array}$ & Tambun - Graha Prima & 8 & aktif \\
\hline 6 & $\mathrm{~K}-16 \mathrm{C}$ & $\begin{array}{l}\text { Terminal Bekasi - Tambun - Perum } \\
\text { Griya Asri }\end{array}$ & 12 & aktif \\
\hline 7 & $\mathrm{~K}-17$ & Cikarang - Cibarusah PP & 355 & aktif \\
\hline 8 & $\mathrm{~K}-18$ & Cikarang - Sukatani PP & 149 & aktif \\
\hline 9 & $\mathrm{~K}-18 \mathrm{~A}$ & $\begin{array}{l}\text { Cikaarang - Sukatani - Muara } \\
\text { Gembong PP }\end{array}$ & 37 & aktif \\
\hline 10 & $\mathrm{~K}-23$ & Tambun - Cimuning - Setu PP & 5 & aktif \\
\hline 11 & K -29 & $\begin{array}{l}\text { Cikarang - Bojong - Pabayuran-Sb } \\
\text { Urip - Kp Garon PP }\end{array}$ & 24 & aktif \\
\hline 12 & K -29 A & Cikarang - Pebayuran PP & 3 & aktif \\
\hline 13 & K -29 B & $\begin{array}{l}\text { Cikarang - Lm Abang - Kp juang - } \\
\text { Rw Kuda - Kp Kramat- Pabayuran } \\
\text { PP }\end{array}$ & 6 & aktif \\
\hline 14 & $\mathrm{~K}-32$ & $\begin{array}{l}\text { Cikarang - Wr Bongkok - Sk Danau } \\
\text { PP }\end{array}$ & 74 & aktif \\
\hline 15 & $\mathrm{~K}-32 \mathrm{~A}$ & Cikarang - Cibitung - MM 2100 PP & 5 & aktif \\
\hline 16 & $\mathrm{~K}-33$ & $\begin{array}{l}\text { Cikarang - Lm Abang - Psr } \\
\text { Gombong - Serang PP }\end{array}$ & 117 & aktif \\
\hline 17 & $\mathrm{~K}-35$ & $\begin{array}{l}\text { Cikarang - Lm abang - Tegal Danas } \\
\text { - Sukamahi PP }\end{array}$ & 67 & aktif \\
\hline 18 & $\mathrm{~K}-38$ & Cikarang - Sukamantri - Pule PP & 57 & aktif \\
\hline 19 & $\mathrm{~K}-39$ & Terminal Bekasi - Pasar Tambun & 29 & aktif \\
\hline 20 & $\mathrm{~K}-39 \mathrm{~B}$ & Terminal Bekasi - Kompas & 20 & aktif \\
\hline 21 & $\mathrm{~K}-39 \mathrm{C}$ & $\begin{array}{l}\text { Cikarang - Cibitung - SKU - Graha } \\
\text { Prima PP }\end{array}$ & 49 & aktif \\
\hline
\end{tabular}




\begin{tabular}{|c|c|c|c|c|}
\hline N0 & $\begin{array}{l}\text { NOMOR } \\
\text { TRAYEK }\end{array}$ & URAIAN TRAYEK & $\begin{array}{l}\text { JUMLAH } \\
\text { ARMADA }\end{array}$ & KET. \\
\hline 22 & $\mathrm{~K}-42$ & $\begin{array}{l}\text { Cikarang - Lm Abang - Psr } \\
\text { Gombong - Lippo City PP }\end{array}$ & 44 & aktif \\
\hline 23 & $\mathrm{~K}-51$ & $\begin{array}{l}\text { Cabang bugin - Bojong Karatan - } \\
\text { Taruma jaya - Marunda PP }\end{array}$ & 14 & aktif \\
\hline 24 & $\mathrm{~K}-52$ & Cikarang - Citarik - Tg Danas PP & 21 & aktif \\
\hline 25 & K -53 & Sukatani - Bojong - Pabayuran PP & 3 & aktif \\
\hline 26 & $\mathrm{~K}-57$ & $\begin{array}{l}\text { Cikarang - Kalijaya - Tambelang } \\
\text { PP }\end{array}$ & 3 & aktif \\
\hline 27 & K - 99 & $\begin{array}{l}\text { Kawasan Jababeka I - Perum } \\
\text { Cikarang Baru PP }\end{array}$ & 25 & aktif \\
\hline 28 & $\mathrm{~K}-61$ & $\begin{array}{l}\text { Cibitung ( Sn Jaya ) - Tg Gede }-\mathrm{Tg} \\
\text { Danas PP }\end{array}$ & 40 & aktif \\
\hline 29 & $\mathrm{~K}-35 . \mathrm{A}$ & $\begin{array}{l}\text { Sukamahi - Cicau - Cilangkara - Sn } \\
\text { Jaya-Cikutul - Cibarusah PP }\end{array}$ & 16 & aktif \\
\hline 30 & $\mathrm{~K}-36$ & $\begin{array}{l}\text { Terminal Bekasi - Tambun - CBL } \\
\text { PP }\end{array}$ & 15 & aktif \\
\hline 31 & $\mathrm{~K}-36 \mathrm{~B}$ & $\begin{array}{l}\text { Ps. H. Malik - Bojong Koneng - } \\
\text { CBL - Tanah Angke PP }\end{array}$ & 12 & aktif \\
\hline
\end{tabular}

Sumber : Dinas Perhubungan Kabupaten Bekasi, 2014 \& sumber-sumber lain.

Tabel. : Daftar nama trayek yang melayani sekitar Stasiun Tambun

\begin{tabular}{||c|l|l|c|l||}
\hline NO & $\begin{array}{l}\text { NOMOR } \\
\text { TRAYEK }\end{array}$ & \multicolumn{1}{|c||}{ URAIAN TRAYEK } & $\begin{array}{c}\text { JUMLAH } \\
\text { ARMADA }\end{array}$ & \multicolumn{1}{|c||}{ KET. } \\
\hline \hline 1 & $\mathrm{~K}-01 \mathrm{~A}$ & Stasiun Bekasi - Tambun - Cikarang & 43 & AKDP \\
\hline 2 & $\mathrm{~K}-16$ & $\begin{array}{l}\text { Tambun - Tambelang - Balong } \\
\text { asem pp }\end{array}$ & 10 & Angdes \\
\hline 3 & $\begin{array}{l}\mathrm{K}-16 \\
\mathrm{BV}\end{array}$ & Tambun - Perum Villa Bekasi Indah. & 14 & Angdes \\
\hline 4 & $\begin{array}{l}\mathrm{K}-16 \\
\text { BG }\end{array}$ & Tambun - Graha Prima & 8 & Angdes \\
\hline 5 & $\mathrm{~K}-16 \mathrm{C}$ & $\begin{array}{l}\text { Terminal Bekasi - Tambun - Perum } \\
\text { Griya Asri }\end{array}$ & 12 & Angdes \\
\hline 6 & $\mathrm{~K}-39$ & Terminal Bekasi - Pasar Tambun & 29 & Angdes \\
\hline 7 & $\mathrm{~K}-39$ B & Terminal Bekasi - Kompas & 20 & Angdes \\
\hline 8 & $\mathrm{~K}-23$ & Tambun - Cimuning - Setu PP & 5 & Angdes \\
\hline 9 & $\mathrm{~K}-36$ & Terminal Bekasi - Tambun - CBL & 15 & Angdes \\
\hline
\end{tabular}

Sumber : Hasil Inventarisasi, 2019 


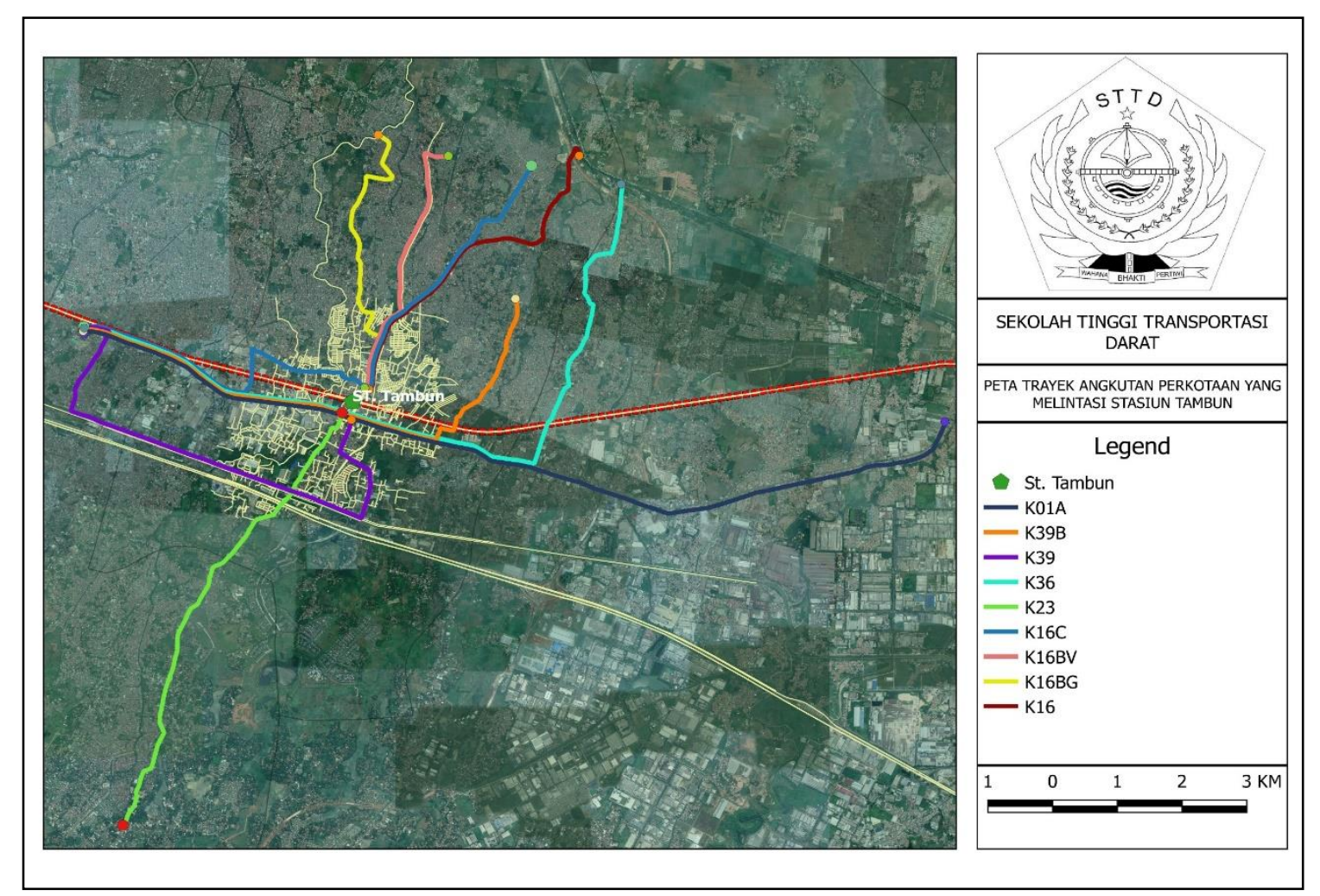

Gambar : Peta Trayek Angkutan Umum yang Melintasi Stasiun Tambun

\section{FAKTOR MUATAN}

Tabel : Faktor muat rata-rata setiap Rute

\begin{tabular}{|c|c|c|c|c|c|c|}
\hline \multirow[t]{2}{*}{ NO } & \multirow{2}{*}{$\begin{array}{l}\text { NOMOR } \\
\text { TRAYEK }\end{array}$} & \multicolumn{3}{|c|}{ LOAD FACTOR (\%) } & \multirow{2}{*}{$\begin{array}{l}\text { RATA- } \\
\text { RATA }\end{array}$} & \multirow{2}{*}{$\begin{array}{l}\text { PENILAIAN LOAD } \\
\text { FACTOR }\end{array}$} \\
\hline & & Peak Pagi & Peak siang & Peak sore & & \\
\hline 1 & $\mathrm{~K}-01 \mathrm{~A}$ & 64.28 & 40.00 & 12.86 & 39.05 & $<70 \%$ \\
\hline 2 & $K-16$ & 41.07 & 19.64 & 19.05 & 26.59 & $<70 \%$ \\
\hline 3 & $\mathrm{~K}-16 \mathrm{BV}$ & 30.95 & 21.43 & 9.52 & 20.63 & $<70 \%$ \\
\hline 4 & $\mathrm{~K}-16 \mathrm{BG}$ & 38.57 & 30.00 & 47.51 & 38.69 & $<70 \%$ \\
\hline 5 & $K-16 C$ & 41.67 & 42.86 & 51.19 & 45.24 & $<70 \%$ \\
\hline 6 & K - 39 & 42.86 & 54.76 & 52.38 & 50.00 & $<70 \%$ \\
\hline 7 & $K-39 B$ & 25.00 & 8.93 & 21.43 & 18.45 & $<70 \%$ \\
\hline 8 & $K-23$ & 55.21 & 16.67 & 77.08 & 49.65 & $<70 \%$ \\
\hline
\end{tabular}




\begin{tabular}{|c|c|c|c|c|c|c|}
\hline NO & NOMOR & \multicolumn{3}{|c|}{ LOAD FACTOR (\%) } & \multirow{2}{*}{$\begin{array}{c}\text { RATA- } \\
\text { RATA }\end{array}$} & $\begin{array}{c}\text { PENILAIAN LOAD } \\
\text { FACTOR }\end{array}$ \\
\cline { 3 - 5 } & TRAYEK & Peak Pagi & Peak siang & Peak sore & RAT \\
\hline 9 & $\mathrm{~K}-36$ & 41.07 & 28.57 & 30.36 & 33.33 & $<70 \%$ \\
\hline
\end{tabular}

Sumber : Hasil Survei \& Analisis, 2019

Faktor muat angkutan pedesaan yang melayani disekitar wilayah Stasiun Tambun, Kabupaten Bekasi bervariasi, dimana rata-rata faktor muat angkutan umum adalah dibawah $70 \%$.

\section{KAPASITAS PELAYANAN}

Kapasitas pelayanan merupakan jumlah muatan penumpang maksimum (kapasitas) yang disediakan oleh pelayanan suatu trayek angkutan dalam tempo waktu tertentu. Berdasarkan pengolahan data hasil kompilasi dan verifikasi data survai menunjukkan bahwa kapasitas pelayanan angkutan pedesaan di Kabupaten Bekasi adalah sebesar $\underline{\mathbf{9 . 3 9 2}}$ penumpang per hari, yang terdiri dari 9 trayek. Nilai ini diperoleh dari penjumlahan kapasitas penumpang di semua trayek yang merupakan fungsi perkalian antara kapasitas jenis kendaraan layanan, jumlah kendaraan beroperasi dan jumlah rit/hari.

Secara terperinci jumlah kapasitas pelayanan per hari untuk setiap trayek dapat disajikan dalam Tabel berikut:

Tabel : Data kapasitas pelayanan angkutan umum di sekitar Stasiun Tambun

\begin{tabular}{|c|l|c|c|c|c|c|}
\hline N0 & $\begin{array}{c}\text { NOMOR } \\
\text { TRAYEK }\end{array}$ & $\begin{array}{c}\text { Jenis } \\
\text { kendaraan }\end{array}$ & $\begin{array}{c}\text { kapasitas } \\
\text { kendaraan }\end{array}$ & $\begin{array}{c}\text { Jumlah } \\
\text { Kendaraan } \\
\text { Beroperasi }\end{array}$ & $\begin{array}{c}\text { Jumlah Rit } \\
\text { / Hari }\end{array}$ & $\begin{array}{c}\text { kapasitas } \\
\text { pelayanan /hari }\end{array}$ \\
\hline 1 & K - 01 A & $\begin{array}{c}\text { Bus } \\
\text { Sedang }\end{array}$ & 16 & 43 & 5 & 3.440 \\
\hline 2 & K - 16 & MPU & 12 & 10 & 6 & 720 \\
\hline 3 & K - 16 BV & MPU & 12 & 14 & 4 & 672 \\
\hline 4 & K - 16 BG & MPU & 12 & 8 & 5 & 480 \\
\hline 5 & K - 16 C & MPU & 12 & 12 & 4 & 576 \\
\hline 6 & K - 39 & MPU & 12 & 29 & 3 & 1.044 \\
\hline 7 & K - 39 B & MPU & 12 & 20 & 5 & 1.200 \\
\hline 8 & K - 23 & MPU & 12 & 5 & 6 & 360 \\
\hline 9 & K - 36 & MPU & 12 & 15 & 5 & 900 \\
\hline & & & & Jumlah & 9.392 \\
\hline
\end{tabular}




\section{VOLUME PERMINTAAN}

Volume permintaan pelayanana angkutan umum merupakan jumlah penumpang yang telah diangkut dalam satuan waktu tertentu, yang dapat diukur dalam satuan waktu per hari atau per jam sibuk dan jam sepi.

Hasil pengolahan data menunjukkan bahwa volume permintaan pelayanan angkutan pedesaan di Kabupaten Bekasi adalah sebesar $\underline{\mathbf{5 . 9 9 6}}$ penumpang per hari dari keseluruhan trayek yang melayani di sekitar Stasiun Tambun, yang berjumlah 9 trayek. Secara terperinci jumlah kapasitas pelayanan angkutan umum/pedesaan di Kabupaten Bekasi per hari untuk masing-masing trayek dapat disajikan dalam Tabel berikut:

Tabel : Volume Permintaan Pelayanan Angkutan Umum,

Di Sekitar Stasiun Tambun

\begin{tabular}{|c|c|c|c|c|c|c|c|}
\hline NO & $\begin{array}{l}\text { NOMOR } \\
\text { TRAYEK }\end{array}$ & $\begin{array}{c}\text { Jenis } \\
\text { Kendaraan }\end{array}$ & $\begin{array}{l}\text { Kapasitas } \\
\text { Kendaraan }\end{array}$ & $\begin{array}{c}\text { Load } \\
\text { Faktor } \\
\text { Dinamis } \\
(\%)\end{array}$ & $\begin{array}{c}\text { Kendaraan } \\
\text { yang } \\
\text { Beroperasi }\end{array}$ & $\begin{array}{l}\text { Jumlah } \\
\text { Rit / } \\
\text { Hari }\end{array}$ & $\begin{array}{c}\text { Jumlah } \\
\text { Penumpang / } \\
\text { Hari }\end{array}$ \\
\hline 1 & $\mathrm{~K}-01 \mathrm{~A}$ & $\begin{array}{c}\text { Bus } \\
\text { Sedang }\end{array}$ & 16 & 60,95 & 43 & 5 & 2.064 \\
\hline 2 & K - 16 & MPU & 12 & 59,03 & 10 & 6 & 425 \\
\hline 3 & $\begin{array}{l}\text { K - } 16 \\
\text { BV }\end{array}$ & MPU & 12 & 66,59 & 14 & 4 & 444 \\
\hline 4 & $\begin{array}{l}\mathrm{K}-16 \\
\mathrm{BG}\end{array}$ & MPU & 12 & 76,90 & 8 & 5 & 365 \\
\hline 5 & K - $16 \mathrm{C}$ & MPU & 12 & 64,95 & 12 & 4 & 368 \\
\hline 6 & K - 39 & MPU & 12 & 63,82 & 29 & 3 & 657 \\
\hline 7 & $K-39 B$ & MPU & 12 & 79,65 & 20 & 5 & 948 \\
\hline 8 & $K-23$ & MPU & 12 & 69,32 & 5 & 6 & 248 \\
\hline 9 & $K-36$ & MPU & 12 & 53,56 & 15 & 5 & 477 \\
\hline & & & & & & Jumlah & 5.996 \\
\hline
\end{tabular}

Sumber : Hasil Analisis, 2019

\section{ASAL DAN TUJUAN PERJALAN}

Asal perjalanan dari responden di Stasiun Tambun, sebahagian besar adalah dari wilayah Tambun $(83,6 \%)$, diikuti oleh Kecamatan Cibitung $(2,6 \%)$ dan dari arah Karawang $(2,6 \%)$, Kecamatan Bekasi Timur (1,8\%), Kecamatan Mustika Jaya (1,2\%), Kecamatan Setu $(1,2 \%)$, rincian asal perjalanannya sebagaimana Tabel berikut. 
Tabel : Asal Perjalanan di Stasiun Tambun

\begin{tabular}{|c|c|c|c|c|c|c|c|}
\hline \multirow{3}{*}{$\begin{array}{ll} & \text { No. } \\
\text { A } & \\
\end{array}$} & \multicolumn{3}{|c|}{ Asal Perjalanan Responden } & \multirow{2}{*}{\multicolumn{2}{|c|}{$\begin{array}{c}\text { Asal Perjalanan Populasi } \\
\text { Jumlah }\end{array}$}} & \multirow{2}{*}{\multicolumn{2}{|c|}{ Prosentase }} \\
\hline & \multirow{2}{*}{$\frac{\text { Kota/ Kab/ Kecamatan }}{\text { KABUPATEN BEKASI }}$} & \multicolumn{2}{|c|}{ Jumlah } & & & & \\
\hline & & 444 & & 12.004 & & $88,8 \%$ & \\
\hline 1 & Cibitung & & 13 & & 351 & & $2,6 \%$ \\
\hline 2 & Cikarang Selatan & & 1 & & 27 & & $0,2 \%$ \\
\hline 3 & Cikarang Timur & & 2 & & 54 & & $0,4 \%$ \\
\hline 4 & Cikarang Utara & & 3 & & 81 & & $0,6 \%$ \\
\hline 5 & Setu & & 6 & & 162 & & $1,2 \%$ \\
\hline 6 & Sukatani & & 1 & & 27 & & $0,2 \%$ \\
\hline 7 & Tambun & & 418 & & 11.301 & & $83,6 \%$ \\
\hline B & KARAWANG & 13 & & 351 & & $2,6 \%$ & \\
\hline 1 & Karawang & & 13 & & 351 & & $2,6 \%$ \\
\hline C & KOTA BEKASI & 43 & & 1.163 & & $8,6 \%$ & \\
\hline 1 & Bantargebang & & 1 & & 27 & & $0,2 \%$ \\
\hline 2 & Bekasi Barat & & 3 & & 81 & & $0,6 \%$ \\
\hline 3 & Bekasi Selatan & & 1 & & 27 & & $0,2 \%$ \\
\hline 4 & Bekasi Timur & & 9 & & 243 & & $1,8 \%$ \\
\hline 5 & Bekasi Utara & & 6 & & 162 & & $1,2 \%$ \\
\hline 6 & Jatiasih & & 5 & & 135 & & $1,0 \%$ \\
\hline 7 & Medan Satria & & 3 & & 81 & & $0,6 \%$ \\
\hline 8 & Mustika Jaya & & 6 & & 162 & & $1,2 \%$ \\
\hline 9 & Pondok Gede & & 4 & & 108 & & $0,8 \%$ \\
\hline 10 & Pondok Melati & & 1 & & 27 & & $0,2 \%$ \\
\hline 11 & Rawalumbu & & 4 & & 108 & & $0,8 \%$ \\
\hline & Jumlah & 500 & 500 & 13.518 & 13.518 & $100,0 \%$ & $100,0 \%$ \\
\hline
\end{tabular}

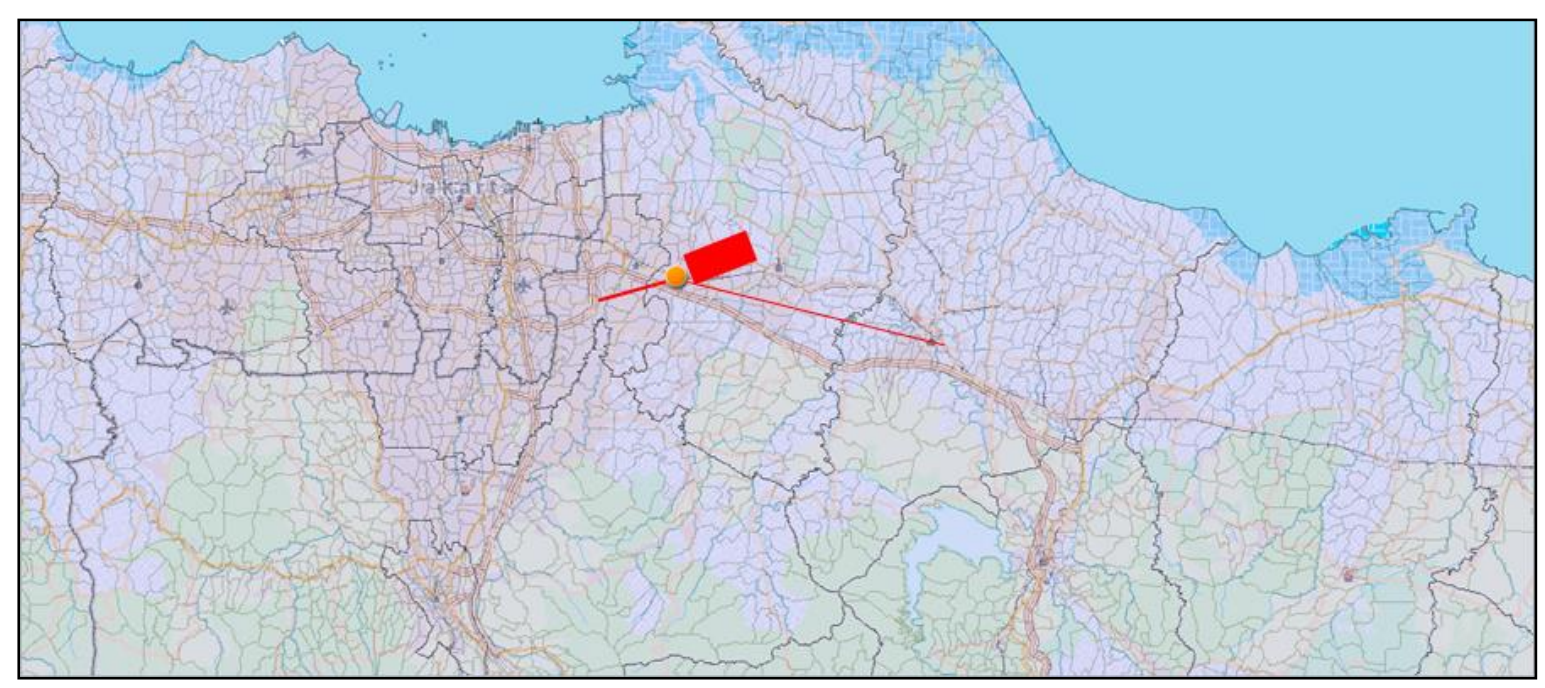

Gambar : Desire line asal perjalanan penumpang KA di Stasiun Tambun 
Adapun tujuan perjalanan dari responden di Stasiun Tambun, utamanya menuju DKI Jakarta (75,8\%), Kabupaten Bekasi (11,4\%), Depok (4,2\%), Kota Bekasi (3,8\%), dan Karawang (2,2\%), sedangkan wilayah lainnya adalah Bogor dan Tangerang sekitar $1 \%$. Secara rinci tujuan perjalanannya adalah sebagaiman Tabel 5.7.

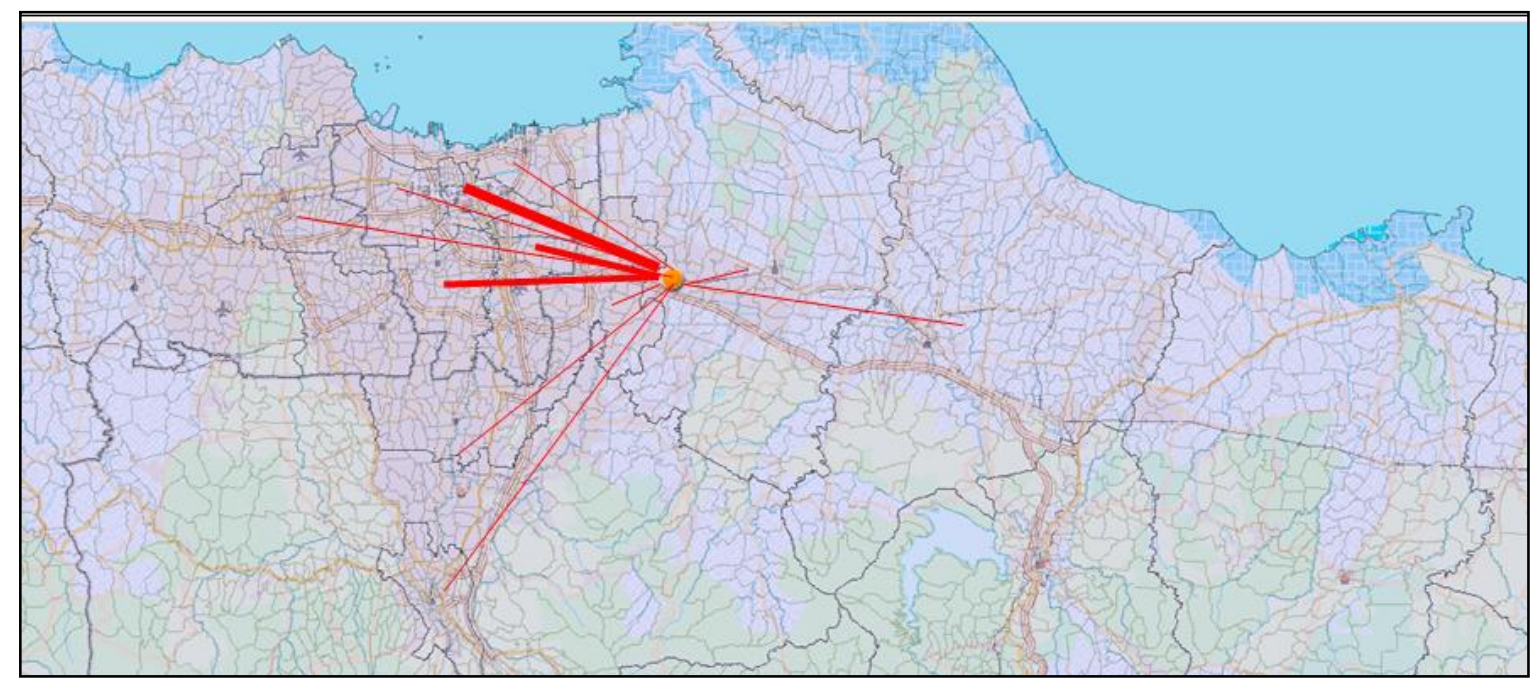

Gambar : Desire line tujuan perjalanan penumpang KA dari Stasiun Tambun

Tabel : Tujuan Perjalanan dari Stasiun Tambun

\begin{tabular}{|c|c|c|c|c|c|c|c|}
\hline \multirow{3}{*}{$\begin{array}{ll} & \text { No. } \\
\text { A } & \\
\end{array}$} & \multicolumn{3}{|c|}{ Tujuan Perjalanan Responden } & \multirow{2}{*}{\multicolumn{2}{|c|}{$\begin{array}{c}\text { Tujuan Perjalanan Populasi } \\
\text { Jumlah }\end{array}$}} & \multirow{2}{*}{\multicolumn{2}{|c|}{ Prosentase }} \\
\hline & \multirow{2}{*}{$\frac{\text { Kab. / Kota }}{\text { JAKARTA }}$} & \multicolumn{2}{|c|}{ Jumlah } & & & & \\
\hline & & 379 & & 10.247 & & $75,8 \%$ & \\
\hline 1 & Jakarta Utara & & 2 & & 54 & & $0,4 \%$ \\
\hline 2 & Jakarta Pusat & & 169 & & 4.569 & & $33,8 \%$ \\
\hline 3 & Jakarta Barat & & 43 & & 1.163 & & $8,6 \%$ \\
\hline 4 & Jakarta Timur & & 106 & & 2.866 & & $21,2 \%$ \\
\hline 5 & Jakarta Selatan & & 59 & & 1.595 & & $11,8 \%$ \\
\hline $\mathrm{B}$ & BOGOR & 8 & & 216 & & $1,6 \%$ & \\
\hline C & DEPOK & 21 & & 568 & & $4,2 \%$ & \\
\hline $\mathrm{D}$ & TANGERANG & 5 & & 135 & & $1,0 \%$ & \\
\hline $\mathrm{E}$ & KARAWANG & 11 & & 297 & & $2,2 \%$ & \\
\hline $\mathrm{F}$ & KAB BEKASI & 57 & & 1.541 & & $11,4 \%$ & \\
\hline G & KOTA BEKASI & 19 & & 514 & & $3,8 \%$ & \\
\hline & Total & 500 & & 13.518 & & $100 \%$ & \\
\hline
\end{tabular}




\section{KEBUTUHAN ANGKUTAN UMUM}

Berdasarkan hasil survei statis dan survei dinamis telah diperoleh jumlah armada yang beroperasi, headway dan jumlah rit per hari dari 9 (sembilan) trayek yang melayani kawasan Stasiun Tambun, Bekasi.

Tabel : Angkutan Umum di Stasiun Tambun

\begin{tabular}{|c|l|c|c|c|c|c|c|c|c|}
\hline No & $\begin{array}{c}\text { Kode } \\
\text { Trayek }\end{array}$ & $\begin{array}{c}\text { Jumlah } \\
\text { Armada }\end{array}$ & $\begin{array}{c}\text { LF } \\
\text { Rata- } \\
\text { rata } \\
(\%)\end{array}$ & $\begin{array}{c}\text { Kapasitas } \\
\text { Kendaraan }\end{array}$ & $\begin{array}{c}\text { Jumlah } \\
\text { Rit/ Hari }\end{array}$ & $\begin{array}{c}\text { LF } \\
\text { Dinamis } \\
(\%)\end{array}$ & $\begin{array}{c}\text { Waktu } \\
\text { tempuh } \\
\text { (menit) }\end{array}$ & $\begin{array}{c}\text { Headway } \\
\text { saat ini }\end{array}$ & $\begin{array}{c}\text { Waktu } \\
\text { Operasi }\end{array}$ \\
\hline 1 & K-01 A & 43 & 39.05 & 16 & 5 & 60,95 & 50 & 5 & $05.00-22.00$ \\
\hline 2 & K-16 & 10 & 26.59 & 12 & 6 & 59,03 & 25 & 15 & $06.00-21.00$ \\
\hline 3 & K-16 BV & 14 & 20.63 & 12 & 4 & 66,59 & 20 & 15 & $06.00-21.00$ \\
\hline 4 & K-16 BG & 8 & 38.69 & 12 & 5 & 76,9 & 25 & 15 & $05.00-21.00$ \\
\hline 5 & K-16 C & 12 & 45.24 & 12 & 4 & 64,95 & 40 & 20 & $06.00-21.00$ \\
\hline 6 & K-39 & 29 & 50.00 & 12 & 3 & 63,82 & 30 & 15 & $06.00-21.00$ \\
\hline 7 & K-39 B & 20 & 18.45 & 12 & 5 & 79,65 & 35 & 20 & $06.00-21.00$ \\
\hline 8 & K-23 & 5 & 49.65 & 12 & 6 & 69,32 & 40 & 15 & $06.00-21.00$ \\
\hline 9 & K- -36 & 15 & 33.33 & 12 & 5 & 53,56 & 50 & 7 & $05.00-21.00$ \\
\hline & Jumlah & 156 & & & & & & & 7 \\
\hline
\end{tabular}

Dalam rangka memenuhi keinginan masyarakat, maka direncanakan layanan angkutannya sebagaimana Tabel 5.8, utamanya pada penetapan headway maksimum 5 menit dan jam operasi menjadi 17 jam (05.00-22.00), dan diperoleh bahwa jumlah total kendaraan yang diperlukan adalah 141 (seratus empat puluh satu) kendaraan, dan hal ini masih dapat dilayani oleh jumlah kendaraan yang beroperasi saat ini (156 kendaraan).

Tabel : Rencana Operasi Angkutan Umum Jalan, di Stasiun Tambun.

\begin{tabular}{|c|l|c|c|c|c|c|c|c|c|}
\hline No & $\begin{array}{c}\text { Kode } \\
\text { Trayek }\end{array}$ & $\begin{array}{c}\text { Waktu } \\
\text { tempuh } \\
\text { (menit) }\end{array}$ & $\begin{array}{c}\text { RTT } \\
\text { (Menit) }\end{array}$ & $\begin{array}{c}\text { Headway } \\
\text { saat ini }\end{array}$ & $\begin{array}{c}\text { Jam } \\
\text { Operasi }\end{array}$ & $\begin{array}{c}\text { Headway } \\
\text { rencana }\end{array}$ & $\begin{array}{c}\text { Kebutuhan } \\
\text { Kendaraan }\end{array}$ & $\begin{array}{c}\text { Juml. } \\
\text { Rit/ } \\
\text { Hari }\end{array}$ & $\begin{array}{c}\text { Renc. } \\
\text { kapasitas } \\
\text { layanan } \\
\text { /hari }\end{array}$ \\
\hline 1 & $\mathrm{~K}-01 \mathrm{~A}$ & 50 & 110 & 5 & 17 & 5 & 22 & 9 & 3.168 \\
\hline 2 & $\mathrm{~K}-16$ & 25 & 55 & 15 & 17 & 5 & 11 & 18 & 2.376 \\
\hline 3 & $\mathrm{~K}-16 \mathrm{BV}$ & 20 & 44 & 15 & 17 & 5 & 9 & 23 & 2.484 \\
\hline 4 & $\mathrm{~K}-16 \mathrm{BG}$ & 25 & 55 & 15 & 17 & 5 & 11 & 18 & 2.376 \\
\hline 5 & $\mathrm{~K}-16 \mathrm{C}$ & 40 & 88 & 20 & 17 & 5 & 18 & 11 & 2.376 \\
\hline 6 & $\mathrm{~K}-39$ & 30 & 66 & 15 & 17 & 5 & 14 & 15 & 2.520 \\
\hline 7 & $\mathrm{~K}-39 \mathrm{~B}$ & 35 & 77 & 20 & 17 & 5 & 16 & 13 & 2.496 \\
\hline 8 & $\mathrm{~K}-23$ & 40 & 88 & 15 & 17 & 5 & 18 & 11 & 2.376 \\
\hline 9 & $\mathrm{~K}-36$ & 50 & 110 & 7 & 17 & 5 & 22 & 9 & 2.376 \\
\hline & Jumlah & & & & & & 141 & & 22.548 \\
\hline
\end{tabular}




\section{PENATAAN TRAYEK}

Mengenai angkutan umum di sekitar stasiun Tambun, khususnya jaringan trayek pedesaan di Kabupaten Bekasi berkaitan dengan peningkatan Stasiun Tambun, maka dapat disimpulkan bahwa:

1) Untuk pergerakan jarak jauh dan memengah sudah cukup dijangkau oleh angkutan umum yang ada yaitu Angkutan K - 01A untuk pergerakan di jalur utama Kabupaten Bekasi.

2) Sedangkan untuk wilayah Utara dan Selatan pada kisaran zona atau kecamatan sekitar Stasiun Tambun sudah dapat dilayani oleh angkutan K - 16, K - 16 BV, K - 16 BG, K $16 \mathrm{C}, \mathrm{K}-39, \mathrm{~K}-39 \mathrm{~B}, \mathrm{~K}-23, \mathrm{~K}-36$.

3) Yang menjadi masalah adalah layanan angkutan umum, diantaranya adalah jadwal perjalanan dan headway yang tidak jelas, khususnya dengan kebiasaan untuk ngetem menunggu calon penumpang.

Untuk itu perlu dilakukan penataan operasional angkutan umum di sekitar Stasiun Tambun, dengan meningkatkan headway menjadi setiap 5 menit pada jam sibuk dan meningkatkan waktu operasional angkutan umum dari rata-rata 13 jam menjadi 17 jam (05.00-22.00).

\section{KESIMPULAN}

Memperhatikan hasil survei dan analisis, dapat disimpulkan beberapa hal, yaitu:

1) Sejak dibukanya layanan kereta api dari Cikarang-Jakarta yang juga melayani Stasiun Tambun, jumlah penumpang yang naik/ turun di Stasiun Tambun terus meningkat, dari data bulan Januari 2019 tercatat sudah mencapai 13.518 penumpang/ hari;

2) Karakteristik penumpang kereta api di Stasiun Tambun, umumnya menggunakan sepeda motor dan ojek (total sekitar 60\%), dan hanya $23 \%$ yang menggunakan angkutan umum;

3) Walaupun penumpang kereta api di Stasiun Tambun dominan (70\%) menyatakan bahwa layanan angkutan umum baik, namun hanya 30\% dari non-pengguna angkutan umum yang bersedia pindah moda ke angkutan umum jika disediakan layanan angkutan;

4) $97 \%$ pengguna KA di Stasiun Tambun mengeluarkan dana untuk transportasi dibawah Rp. 1 juta, dan $56 \%$ penumpang menyatakan bahwa nilai pengeluaran untuk transport masih dibawah $10 \%$ dari pendapatannya; 
5) Saat ini terdapat 9 trayek angkutan umum dengan jumlah kendaraan 156 unit yang dapat melayani penumpang menuju/ meninggalkan Stasiun Tambun, Bekasi; namun dengan kinerja yang kurang baik dan cenderung buruk;

6) Peningkatan layanan angkutan umum dapat diutamakan khususnya pada headway, penjadwalan (menghilangkan ngetem) dan memperpanjang jam operasional, dan semuanya masih dapat diakomodir oleh jumlah kendaraan yang beroperasi saat ini (tidak perlu penambahan armada).

\section{REKOMENDASI}

Melihat kondisi lapangan dan hasil analisis, maka terdapat beberapa hal yang dapat direkomendasikan antara lain:

1) Untuk meningkatkan layanan angkutan umum yang beroperasi disekitar Stasiun Tambun; perlu dikaji lebih mendalam mengenai optimalisasi pelayanan angkutan umum perdesaan yang beroperasi di sekitar Stasiun;

2) Untuk meningkatkan layanan terhadap pengguna angkutan umum, maka perlu dipertimbangkan untuk menyediakan fasilitas angkutan umum dan fasilitas pejalan kaki dari/ dan menuju Stasiun Tambun. 